\title{
EDITORIAL \\ SIN UNA CRÓNICA QUE LO ANUNCIARA FRANCISCO ROTHHAMMER RECIBE PREMIO NACIONAL DE CIENCIAS NATURALES 2016
}

\author{
CHRONICLE OF A PRIZE UNFORETOLD: FRANCISCO ROTHHAMMER \\ RECEIVES THE CHILEAN NATIONAL SCIENCE AWARD $2016^{1}$
}

\author{
Calogero M. Santoro ${ }^{2}$, Vivien G. Standen ${ }^{3}$, Dante Angelo ${ }^{3}$ y Vivian Gavilán ${ }^{3}$
}

Recientemente, sin que existiera una "crónica que lo anunciara" (parafraseando a Gabriel García Márquez), ha sido distinguido con el Premio Nacional de Ciencias Naturales 2016 el Dr. Francisco Rothhammer, académico de la Universidad de Tarapacá, habida cuenta de una larga historia de investigación que ha desarrollado, en parte, en el norte de Chile, desde hace unos cincuenta años.

Los vínculos de Francisco Rothhammer con esta Universidad y, en particular, con el Departamento de Antropología y el Museo Arqueológico San Miguel de Azapa no son nuevos, por el contrario, datan desde comienzos de los años mil novecientos setenta, cuando se radica en Arica, por varios meses, con un proyecto de investigación interdisciplinario y multi-institucional, codirigido con el Dr. William J. Schull (genetista norteamericano). Específicamente, establecieron su cuartel de operaciones en lo que era entonces la Hostería Arica, desde donde programaban y realizaban extensas y extenuantes expediciones a la precordillera y altiplano de Arica, con miras a tratar de comprender, transversalmente, la adaptación humana a las condiciones de estrés ambiental provocadas por la altitud y la falta de oxígeno en los altos Andes, fenómeno conocido como hipoxia (soroche en quechua). Aparte del apoyo local entregado por la Junta de Adelanto de Arica, mediante el Plan Andino dirigido por Carlos Solari, el proyecto contó con financiamiento de varios organismos de USA ${ }^{1}$. Desde Chile recibieron el apoyo del Proyecto MAB de UNESCO, y de la Universidad de Chile.

En el epílogo del libro, editado por Schull y Rothhammer (1990) que resume los principales resultados de este proyecto, señalan que
Recently, without a chronicle foretold (to paraphrase Gabriel García Márquez), Dr. Francisco Rothhammer, academic of the Universidad de Tarapacá, was distinguished with the National Science Award 2016 given a long history of research, developed by him in part in northern Chile for the last fifty years.

Dr. Rothhammer's connections with this university, and in particular with the Anthropology Department and the Archaeological Museum San Miguel de Azapa are not new; on the contrary, they date from the beginning of the 1970s, when he settled in Arica for several months with a multidisciplinary and multi-institutional research project, co-directed by Dr. William J. Schull (American geneticist). They established their center of operations in what was the Hotel Arica, from where they organized and carried out extensive and extenuating expeditions to the Andean pre-cordillera and altiplano of Arica, aiming to transversely understand human adaptation to environmental stress caused by altitude and lack of oxygen in the high Andes, a phenomenon known as hypoxia (soroche in Quechua). In addition to the local support granted by the Junta de Adelanto de Arica, through the Plan Andino directed by Carlos Solari, the project had funding from several organization from the United States ${ }^{1}$. From Chile, they received support from the MAB project from UNESCO and the Universidad de Chile.

In the epilogue of the book edited by Schull and Rothhammer (1990), that summarizes the main results of this project, they write:

\footnotetext{
Translated by Carolina Santoro Arrieta.

Instituto de Alta Investigación, Universidad de Tarapacá, Arica, Chile. calogero_santoro@yahoo.com

Departamento de Antropología, Universidad de Tarapacá, Arica, Chile. vstanden@chungara.cl; dangeloz@gmail.com;

viviangav@yahoo.com
} 
las investigaciones interdisciplinarias se hacen progresivamente más difíciles de realizar, debido en parte a su alto costo, y porque son más tediosas de implementar, que proyectos de investigación de escala menor, con objetivos más acotados y, en parte también, porque el rendimiento de proyectos de esta naturaleza puede que no se observen hasta después de muchos años. De continuar los estudios multidisciplinares, deberíamos ser más eficientes en su organización y gestión (Schull y Rothhammer 1990; ver también Rothhammer et al. 2015).

Esta visión del trabajo científico es la que ha promovido Francisco Rothhammer hasta hoy, lo que le ha permitido configurar equipos de trabajo cada vez más complejos y multidisciplinarios, a escala nacional, continental y mundial, tanto en la Universidad de Chile como con sus colegas del norte del país en la Universidad de Tarapacá.

Entre 1977 y 1980, y debido a su colaboración con la Prof. Patricia Soto Riesle, pasó a formar parte del Departamento de Antropología de la Universidad del Norte de ese entonces, como profesor ad honorem. Esta manera de vincularse desde la capital con esta naciente Universidad de provincia, sin recibir honorarios, es una práctica que hoy es un fósil en el esquema económico nacional, en el que hay poca cabida para la vocación altruista. Esta vinculación siguió luego con la Universidad de Tarapacá hasta el 2003, que incluyó también a otros profesores, nacionales e internacionales, como Juan Munizaga ${ }^{\dagger}$, Virgilio Schiappacasse ${ }^{\dagger}$, Hans Niemeyer ${ }^{\dagger}$, Marvin Allison $^{\dagger}$ y Enrique Gerszten (Arriaza et al. 2015); quienes junto a los equipos locales han venido perfilando la visibilidad y solidez académica de esta Unidad. Desde el 2006 Francisco es Profesor Titular del Instituto de Alta Investigación de nuestra Universidad.

Los vínculos y colaboraciones científicas con académicos de esta y otras Universidades en el campo de la arqueología y la antropología biológica, que ha incluido a profesores como Gonzalo Ampuero, Bernardo Arriaza, Tom Dillehay, Lautaro Núñez, Silvia Quevedo, Mario Rivera, Patricia Soto, y los firmantes de esta editorial (VGS y CMS), a los que se suman Pilar Carvallo, José Cocilovo, Elena Llop, Mauricio Moraga y Germán Manríquez (por
Investigations of the kind that we have described grow progressively more difficult, partly because of their cost, partly because multidisciplinary studies are more tedious to implement than smaller investigations with a narrower range of objectives, and partly because their full return may not be realized for years. If multi-disciplinary studies are to continue, as they should, we must become more efficient in their organization and management (Schull and Rothhammer 1990; see also Rothhammer et al. 2015).

This view on scientific work is what Dr. Rothhammer continues to promote up until this day. It has allowed him to form increasingly complex and multidisciplinary teams at a national, continental, and global scale, in the Universidad de Chile as well as with his colleagues in northern Chile in the Universidad de Tarapacá.

Between 1977 and 1980, given his collaboration with Prof. Patricia Soto Riesle, he became part of the Anthropology Department of the Universidad del Norte, at the time as an ad-honorem professor. This way of creating a link, from the capital of the country, with this newly-formed provincial university without receiving pay is a practice that is a fossil in today's national economic scheme, in which there is little room for altruistic vocation. This connection continued with the Universidad de Tarapacá until 2003, which also included other professors of national and international renown like Juan Munizaga ${ }^{\dagger}$, Virgilio Schiappacasse ${ }^{\dagger}$, Hans Niemeyer ${ }^{\dagger}$, Marvin Allison ${ }^{\dagger}$, and Enrique Gerszten (Arriaza et al. 2015), who along with local teams have shaped the academic visibility and solidity of this academic unit. Dr. Rothhammer has had tenure since 2006 in the Instituto de Alta Investigación of our University.

The connections and scientific collaborations with academics of this and other universities in the field of archaeology and biological anthropology, that have included professors like Gonzalo Ampuero, Bernardo Arriaza, Tom Dillehay, Lautaro Núñez, Silvia Quevedo, Mario Rivera, Patricia Soto, and the authors of this editorial (VGS and CMS), along with Pilar Carvallo, José Cocilovo, Elena Llop, Mauricio Moraga, and Germán Manríquez (to name a few), have been acknowledged in coauthorships in 
nombrar algunos), han quedado reconocidos en las coautorías de más de 200 trabajos que Francisco ha publicado en diversas revistas como Nature, Annals of Human Genetics, Human Biology, Human Genetics, PlosOne, Current Anthropology, Latin American Antiquity, American Journal of Physical Anthropology y Chungara Revista de Antropología Chilena, entre otras. A esto se suma su participación y membrecía en comités editoriales y sociedades científicas de Latinoamérica, USA y Europa, en algunas de las cuales fue miembro fundador, como la Asociación Latinoamericana de Antropología Biológica y el Centro de Investigaciones del Hombre en el Desierto (CIHDE), iniciativa de CONICYT que le tocó discutir directamente con Eric Goles cuando este era presidente de dicha institución y Francisco presidente de la Academia de Ciencias de Chile (durante 2000-2001). Francisco ha sido, además, profesor invitado en universidades de Alemania, USA, Bolivia, Brasil, Colombia, Israel, México, Uruguay y ha recibido varios premios y becas, entre las que destacan la Fogarty Center del National Institute of Health (1970) y la Guggenheim Fellowship (1986), todo ello lo distingue como un reconocido científico en el campo de la genética de poblaciones antiguas. Pero a medida que crecía su prestigio y visibilidad intelectual en campos de las ciencias biológicas y sociales ha logrado controlar el canto de las sirenas que llaman a la egolatría. En suma, Francisco ha logrado establecer sólidos y visibles puentes de colaboración entre la genética, la arqueología y la antropología, donde el reconocimiento de innumerables colaboradores está reflejado en las coautorías de las publicaciones y no en la sección de agradecimientos, otro rasgo de su generosa personalidad.

Tal vez su interés por los pueblos originarios, nos ha comentado Francisco, se motivó a consecuencia de la pasión que mantuvo su abuelo materno por los antiguos habitantes del desierto de Atacama; a tal punto que viajaba desde Santiago en el Longino ${ }^{2}$ para participar en expediciones arqueológicas que realizaba el cura alemán (Luis Friedrich; Castro et al. 2015) del pueblo de Pica hacia comienzos del siglo XX. Esta pasión llevó también a su abuelo a recorrer gran parte de Bolivia, lo que quedó archivado en los recuerdos de su familia, mediante fotografías, correspondencia y una publicación dedicada por more than 200 publications by Francisco in diverse journals like Nature, Annals of Human Genetics, Human Biology, Human Genetics, PlosOne, Current Anthropology, Latin American Antiquity, American Journal of Physical Anthropology and Chungara Revista de Antropología Chilena, among others. In addition to the former, he participates and is member of editorial committees and scientific societies in Latin America, USA, and Europe, in some of which he was a founding member, like the Asociación Latinoamericana de Antropología Biológica, and the Centro de Investigaciones del Hombre en el Desierto (CIHDE). CIHDE is a CONICYT (National Commission of Scientific Research and Technology) initiative he had the opportunity of discussing directly with Eric Goles, when the latter was president of said institution, and Dr. Rothhammer was president of the National Science Academy of Chile (during 2000 to 2001). Dr. Rothhammer has also been visiting professor at universities in Germany, USA, Bolivia, Brazil, Colombia, Israel, Mexico, Uruguay, and has received a series of awards and scholarships among which the Fogarty International Center of the National Institutes of Health (1970), and the Guggenheim Fellowship (1986) stand out, all of which distinguishes him as a recognized researcher in the field of archaeogenetics. However, as his prestige and intellectual visibility in the fields of biological and social sciences has grown, he has managed to evade the sirens'song of egomania. In sum, Dr. Rothhammer has established solid and visible bridges of collaboration between genetics, archaeology, and anthropology, where the recognition of innumerable collaborators is reflected in the coauthorships of publications and not in the acknowledgments; yet another aspect of his generous personality.

$D r$. Rothhammer has commented that perhaps his interest in indigenous peoples was motivated by the passion his maternal grandfather had for the ancient inhabitants of the Atacama Desert, to the point of taking the Longino ${ }^{2}$ from Santiago, to participate in archaeological expeditions organized by the German priest (Luis Friedrich; Castro et al. 2015) of the town of Pica towards the beginning of the twentieth century. This passion led his grandfather to also travel across a greater part of Bolivia, which was archived in the memories of his family through photographs, correspondence, and a publication 
Arthur Posnansky. Estos recuerdos que le mostró y contó su madre, posiblemente estimularon el espíritu aventurero de Francisco, con imágenes remotas de gentes y paisajes.

Desde sus inicios como científico se interesó en la microevolución de las poblaciones originarias americanas que se desarrollaron independientemente durante 16 mil años hasta la llegada de los europeos, quienes introdujeron cambios irreversibles en la geografía genética y cultural; por lo que su investigación ha considerado, también, los cambios producidos con posterioridad al encuentro de estos dos mundos. Particularmente logró integrar y ampliar, en forma pionera los objetivos de investigación acerca de genética de poblaciones con problemáticas afines a la arqueología y antropología sudamericana. De esta manera, ha contribuido a comprender cómo la genética humana puede verse reflejada e incluso influir en las dinámicas sociales de las poblaciones amerindias. En este contexto destacan también sus estudios que han buscado establecer una relación entre la genética, el medio ambiente y ciertos comportamientos sicológicos como la esquizofrenia y el déficit atencional (Henríquez-Henríquez et al. 2015).

Sus primeros acercamientos entre la genética y los pueblos originarios los realizó entre los grupos pewenches del sur de Chile hacia fines de los años 1960. En aquella época primaban los enfoques morfológicos respecto de la variabilidad de ciertos rasgos como los caracteres dentales y los dermatoglifos. A partir de esta información estudió la variabilidad entre los grupos yanomami y los chipaya de Bolivia (Murillo et al. 1997; Rothhammer et al. 1973; Rothhammer et al. 1977). Con esta experiencia fue que enfrentó los pioneros estudios genéticos de los grupos aymara del norte de Chile a partir de variaciones antropométricas. En ese contexto ha integrado también ciertos datos lingüísticos para la mejor comprensión de los procesos biológicos y culturales (Llop y Rothhammer 1974; Rothhammer et al. 1979).

Con estas bases teóricas y metodológicas se introdujo de lleno a estudiar las relaciones genéticas de las poblaciones prehispánicas de Arica. Por ejemplo, estudia la microevolución de las poblaciones locales reconociendo el aporte de flujo génico de otras regiones (Rivera y Rothhammer 1986; Rothhammer et al. 1986; Rothhammer et al. 2009).

Actualmente, desde el Instituto de Alta Investigación de la Universidad de Tarapacá lidera en Chile el proyecto "CANDELA" (Consorcio dedicated to Arthur Posnansky. These memories, shown and recounted to him by his mother, possibly stimulated his adventurous spirit with images of remote people and landscapes.

From his beginnings as a scientist, he was interested in the microevolution of American indigenous populations that developed independently during 16,000 years until the arrival of the European, who introduced irreversible changes in the genetic and cultural geography. Hence, his study has also considered the changes generated after the meeting of both worlds. He pioneered in managing to integrate and broaden the research objectives of population genetics with issues similar to archaeology and anthropology. Thus, he has contributed to understand how human genetics can be reflected by or even influence the social dynamics of Amerindian populations. In this context, his studies that have sought to establish a relationship between genetics, environment, and certain psychological disorders like schizophrenia and attention deficit disorder also stand out (Henríquez-Henríquez et al. 2015).

His first attempts at studying genetics and indigenous peoples were carried out among the Pewenches in southern Chile towards the end of the 1960s. At the time, morphological perspectives prevailed over variability in certain features such as dental characters and dermatoglyphics. Based on this information he studied the variability between Yanomami, and the Chipaya of Bolivia (Murillo et al. 1997; Rothhammer et al. 1973; Rothhammer et al. 1977). With this experience under his belt, he tackled the pioneering studies on the genetics of Aymara groups in northern Chile based on anthropometric variations. In this context, he has also integrated certain linguistic data for better comprehension of biological and cultural processes (Llop and Rothhammer 1974; Rothhammer et al. 1979).

With this theoretical and methodological basis, he dedicated himself full time to study the genetic relationships of the pre-Hispanic populations of Arica. For example, he studied the microevolution of local populations recognizing the contribution of gene flow from other regions (Rivera and Rothhammer 1986; Rothhammer et al. 1986; Rothhammer et al. 2009).

Currently, based in the Instituto de Alta Investigación of the Universidad de Tarapacá, he heads in Chile of the CANDELA project (Consorcio 


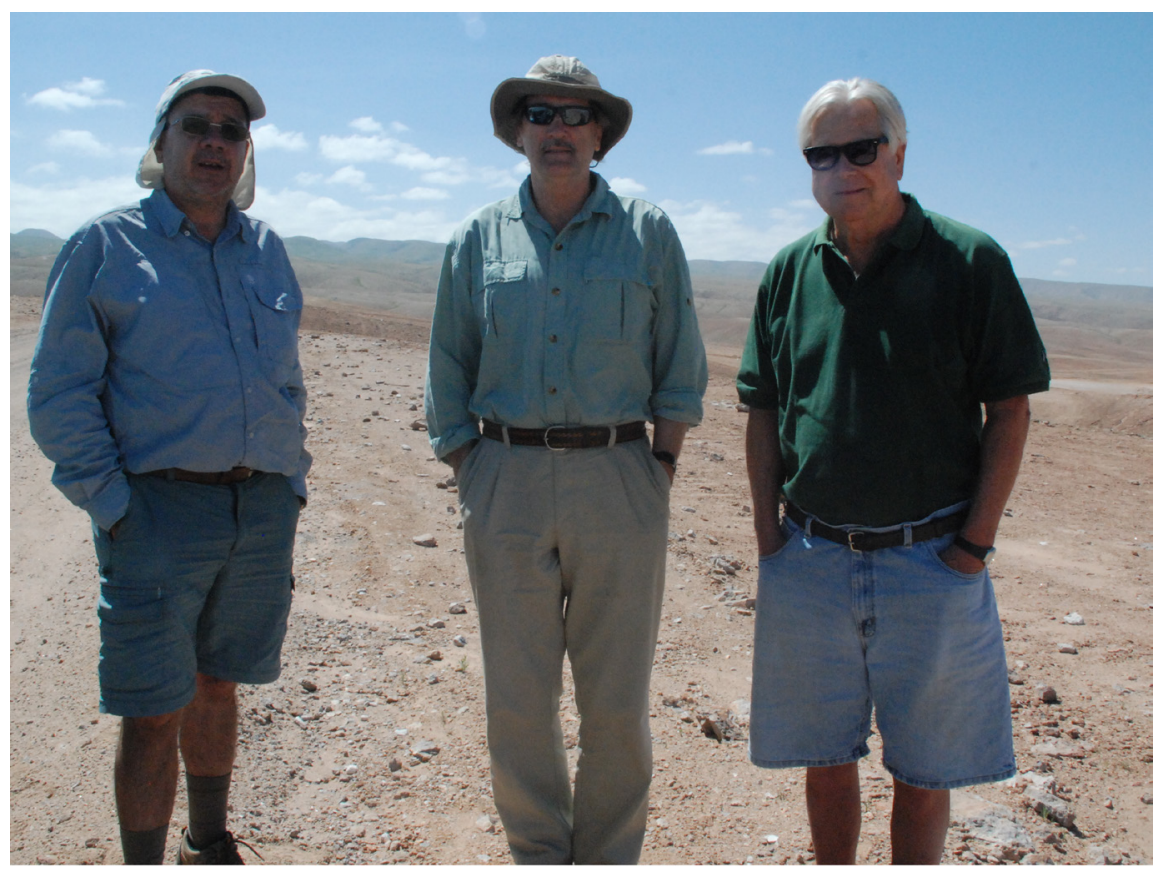

Francisco Rothhammer (derecha) junto a Tom Dillehay (centro) y Calogero Santoro (izquierda) en visita realizada a la precordillera andina de Arica, abril de 2011.

Francisco Rothhammer (right) with Tom Dillehay (center) and Calogero Santoro (left) visiting the Andean precordillera of Arica, April 2011.

para el análisis de la Diversidad y Evolución de Latinoamérica), que incluye el análisis genético de poblaciones latinoamericanas ${ }^{3}$, lo que le ha permitido ponerse en la frontera más innovativa de los estudios genéticos. Los primeros resultados obtenidos para las quince regiones del territorio chileno muestran que sus poblaciones integran de mayor a menor proporción rasgos genéticos amerindios, europeos y africanos. Este esquema genético muestra con mayor precisión las características genotípicas y fenotípicas de la población chilena (Pulgar-Alarcón et al. 2015). También han enfrentado desde una perspectiva continental el problema del origen, antigüedad y flujos migratorios de las poblaciones que colonizaron América (Reich et al. 2012). Finalmente, Francisco ha reflexionado, desde una perspectiva más antropológica, acerca de las prácticas mortuorias Chinchorro (Rothhammer 2014; Santoro et al. 2012) y de los orígenes genéticos y culturales de los mapuche (Dillehay y Rothhammer 2013).

Para otorgarle el Premio Nacional de Ciencias Naturales el jurado valoró fundamentalmente "su destacada labor como genetista en el ámbito de la antropología, cuya centralidad investigativa se ha enfocado en la microevolución de las poblaciones para el análisis de la Diversidad y Evolución de Latinoamérica) that includes the genetic analysis of Latin American populations ${ }^{3}$, which has allowed him to stand on the most innovative frontier of genetic studies. The first results, obtained for all fifteen regions of the Chilean territory, show that its populations integrate proportionally from most to least Amerindian, European, and African genetic traits. This genetic scheme shows with more precision the genotypic and phenotypic characteristics of the Chilean population (Pulgar-Alarcón et al. 2015). They have also analyzed the problem of origin, age, and migratory flows of the populations that colonized America from a continental perspective (Reich et al. 2012). Finally, Francisco has pondered, from a more anthropological perspective, over the mortuary practices of the Chinchorro (Rothhammer 2014; Santoro et al. 2012), and the genetic and cultural origins of the Mapuche (Dillehay and Rothhammer 2013).

In granting him the Chilean National Science Award, the jury valued fundamentally "his outstanding work as a geneticist in the area of anthropology, whose investigative core is focused on the microevolution of American indigenous populations". In 
originarias americanas". Además, valoró que "su trayectoria ha contribuido al conocimiento y al acervo cultural del país." A lo anterior podemos agregar que, aparte de su contribución académica reconocemos en Francisco un ejemplo de honestidad y rigurosidad científica con muy bajo perfil mediático, lo que explica que ninguna "coma" anunciara este Premio. addition, they valued that "his career has contributed to the knowledge and cultural heritage of the country". To the former we may add that besides his academic contribution, we acknowledge Francisco Rothhammer as an example of honesty and scientific rigor with a low media profile, which explains that no one foretold his winning this award.

\section{Referencias Citadas}

Arriaza B., V.G. Standen, C.M. Santoro y J. Hidalgo 2015. De Richmond a Arica: En Memoria de Marvin Jerome Allison. Chungara Revista de Antropología Chilena 47:543-547.

Castro, L., C. Figueroa y H. Hernández 2015. Quehacer y planteamientos del cura Luis Friedrich en el oasis de Pica durante la chilenización de Tarapacá, 1903-1907. HiSTOReLo. Revista de Historia Regional y Local 7:224-257.

Dillehay, T.D. y F. Rothhammer 2013. Quest for the origins and implications for social rights of the Mapuche in the southern cone of South America. Latin American Antiquity 24:149-163.

Henríquez-Henríquez, M., L. Villarroel, H. Henríquez, F. Zamorano, F. Rothhammer y F. Aboitiz 2015. Intratask variability as a correlate for DRD4 and SLC6A3 variants: A pilot study in ADHD. Journal of Attention Disorders 19:987-996.

Llop, E. y F. Rothhammer 1974. Genética de poblaciones aborígenes chilenas. I Representación numérica de la variabilidad genética y su asociación con patrones de diversificación cultural-material lingüística y geográfica. Revista Médica de Chile 102:593-596.

Murillo, F., F. Rothhammer y E. Llop 1997. Dermatoglyphics and ethnic relationships of the Chipaya of Bolivia. American Journal of Physical Anthropology 46:45-50.

Pulgar-Alarcon, I., M. Fuentes-Guajardo, E. Llop y F. Rothhammer 2015. Amerindian admixture estimation based on serological and molecular methods. Revista Medica de Chile 143:439-443.

Reich, D., N. Patterson, D. Campbell, A. Tandon, et al. 2012. Reconstructing native American population history. Nature 488:370-374.

Rivera, M.A. y F. Rothhammer 1986. Evaluación biológica y cultural de poblaciones Chinchorro: nuevos elementos para la hipótesis de contactos transaltiplánicos: cuenca Amazonas-costa Pacífico. Chungara 16-17:295-307.

Rothhammer, F. 2014. En torno a la emergencia de complejidad funeraria temprana en la costa norte de Chile. Chungara Revista de Antropología Chilena 46:145-151.
Rothhammer, F., R. Chakraborty y E. Llop 1977. A collation of marker gene and dermatoglyphic variability at different levels of population differentiation. American Journal of Physical Anthropology 46:51-59.

Rothhammer, F., R. Chakraborty y E. Llop 1979. Dermatoglyphic variation among South-American tribal populations and its association with marker genes; linguistic and geographic distances. En Dermatoglyphics 50 Years Later, editado por C. Plato y V. Werteleki, pp. 269-276. March of Dimes Foundation, New York.

Rothhammer, F., J.V. Neel, F. da Rocha y G. Sundling 1973. The genetic structure of a tribal population,. the Yanomama Indians. VIII Dermatoglypic differences among village. American Journal of Human Genetics 25:152-166.

Rothhammer, F., C.M. Santoro, E. Poulin, M. Moraga y V.G. Standen 2009. Archeological and mtDNA evidence for tropical lowland migrations and cultural change during the Late Archaic / Formative in northern Chile. Revista Chilena de Historia Natural 82:543-552.

Rothhammer, F., M. Fuentes-Guajardo, R. Chakraborty, J.L. Bermejo y M. Dittmar 2015. Neonatal variables, altitude of residence and aymara ancestry in northern Chile. PlosOne http:// dx.doi.org/10.1371/journal.pone.0121834

Rothhammer, F., C. Silva, J.A. Cocilovo y S. Quevedo 1986. Una hipótesis provisional sobre el poblamiento de Chile basada en el análisis multivariado de medidas craneométricas. Chungara 16-17:115-118.

Santoro, C.M., M.M. Rivadeneira, C. Latorre, F. Rothhammer y V.G. Standen 2012. Rise and decline of Chinchorro sacred landscapes along the hyperarid coast of the Atacama Desert. Chungara Revista de Antropología Chilena 44:637-653.

Schull, W.J. y F. Rothhammer (eds.) 1990. The Aymará: Strategies in Human Adaptation to a Rigorous Environment. Kluwer Academic Publishers, Dordrecht.

\section{Notas}

1 National Heart, Lung and Blood Institute, the Institute of General Medical Sciences of the National Institutes of Health, the Wenner-Gren Foundation y the John S. Guggenheim Foundation y del Special Program for Research and Training in Tropical Diseases of the World Health.
2 Tren longitudinal que unía el centro con el extremo norte del país.

3 Esta iniciativa es liderada por el Dr. Andrés Ruiz-Linares del University College London. 